\title{
Re-Visitation of Family Concept with an Educative View in Shakespeare's Titus Andronicus
}

\author{
Casimir Comlan Soede
}

British Literature and Civilization, University of Abomey-Calavi, Bénin

Doi:10.19044/esj.2018.v14n23p196 URL:http://dx.doi.org/10.19044/esj.2018.v14n23p196

\begin{abstract}
The family is the key component of any society whose prosperity and safety depends on the role it plays in children's education. Mistrust is led to hiding of knowledge that can be useful and helpful for youth. Solitude takes place in our community and one must be self-developer of himself or herself. And that force people to fear their neighboring. Society is divided into little groups. It is in that vein that the current research work comes to pinpoint these misconducts that draw way to problems such as murders, terrorism, treachery, robbery, betrayal that the world currently faces. The reader-response and historicism approaches used along the current work, show that the family should change its ways of educating youngsters to enhance their sociopolitical and economic growth. The research argues that members of a family have to share their living experiences within their social groups. In this regards, the study has found that parents and relatives should accept one another by overcoming the social differences (rich and poor) instead of being handicaps for their youth who try to be a Man.
\end{abstract}

Keywords: Solidarity, welfare, morality, jealousy, mistrust

\section{Introduction}

Usually, a newborn baby is the source of joy to its family and relatives. This social reality mainly results from the expectation of the members of that family. When the child grows up and starts acting as a man, the family tends to appreciate his/her growth when he/she behaves according to his/her parents' moral codes. When the contrary occurs, the young person is blamed by the family, leading to conflictual situations within the family. This social phenomenon related to the children's guidance is more visible today in our cultural and traditional environments. The family's role of education via guidance and assistance is missed. The positive traditional and cultural value of family in education field lacks. In that vein, De Dravo (2012:102) quotes the late Pope Jean-Paul II: "Les valeurs positives de la culture africaine sont 
importantes, notamment le sens religieux, l'amour de la vie, la solidarité et le sens communautaire...il n'y a pas jusqu'à l'allaitement maternel qui ne puisse pas intéresser le monde entier..."6. So, by expressing the relationship and solidarity within family members in tradition and culture, African as well as Western people can help its citizens or countrymen to overcome hurdles and reach all the same development level. As evidence from the narrative, Saturninus was granted such a value by his countrymen while he was on the way to gain access to his late father father's throne, Caesar: "...plead my successive title with your swords, I am his first-born son, that was the last that ware the imperial diadem of Rome; then let my father's honors live in me,..." (Shakespeare, 2011: 445). Thus, the solidary manifested through the public or common support, plays a key role in the achievement of one's development and one of his or her belongings.

Therefore, this research work aims at enlightening us on what is unfair, social welfare in general and the individual in particular. It intends to shed light on the risks children run in the educational field. The fulfillment of family's member must be the matter of the whole kinship. The community, and the nation in which individuals live are considered to be part of their family. When they are acting, that key element should be put in mind as it was observed from the side of the Empress Tamora when her son was on the way to be offered in sacrifice for ritual in the souls' peace-keeping of dead Roman soldiers during the battle against Goths:

Victorious Titus, rue the tears I shed, a mother's tears in passion for her son: and if thy sons were ever dear to thee, O, think my son to be as dear to me! Sufficeth not that we are brought to Rome, to beautify thy triumphs and return, captive to thee and to thy Roman yoke, but must my sons be slaughter'd in the streets, for valiant doings in their county's cause? O, if to fight for king and commonweal were piety in thine, it is in these. Andronicus, stain not thy tomb with blood: wilt thou draw near the nature of the gods? Draw near them then in being merciful: sweet mercy is nobility's true badge: thrice noble Titus, spare my first-born son. (Ibid.)

Tamora, firstly as a mother, is suffering for the rubbish (the killing of her elder son) that is going to be committed against her. This is because not only are they the war captives, but they are also the prisoners of Romans. And since that is not much for the Roman Empire, her son was to be offered as a sacrifice in order to appease the so-called soul of dead Romans during the war.

\footnotetext{
${ }^{6}$ See my translation of Jean Paul II about African culture quoted by Marie-José De Dravo in one of her paper published in 2012: "The positive values of African culture are important; mainly in the religious sense, love of life, solidarity and community sense... hence child's milking that won't interest the whole world..."
} 
Besides, as a group member, she manifestes her solidarity to Alarbus through the begging words that she was expressing to the braver of warrior Titus: 'Andronicus, stain not thy tomb with blood', i.e. Titus can avoid committing that sin. And she continues 'sweet mercy is nobility's true badge', i.e he has possibility and he is also granted with goodness. Those words are spoken by her to Titus in order to make him release her group member, a member of her community as well as the one of Goths.

Consequently, the reader-response theory seems useful on the one hand to give a clear understanding of the playwright performance through his writing. On the other hand they help to investigate and make links between our interpretations and the socio-cultural and intellectual events of the period. This theory gives also indications for a clear interpretation of the realities with a close look on tradition, culture, and the social values which exist for the wellbeing of youth. Thus, this study will firstly focus on family as source of youngsters' education for a sustainable development. Secondly, it will give a view of the family concept by the old and new generations with an emphasis on what the youth are undergoing. The third part emphasizes the change of mentality in family roles with a clear view on its socio-political and economic impacts on youth's education.

\section{Family as a Source of Youngsters' Education for a Sustainable Development.}

Far from blaming members of the families, the current section acts to pinpoint the traditional role devolved to family in society. A family is a societal group formed by people living or not. It can be described as a group of people who are closely related by birth, marriage, or adoption (Wehmeier, 2006: 530). In other words, it is a group of people living together and functioning as a single household, usually consisting of parents and their children. In short, a family can be considered as all the people who are descended from a common ancestor (Koyango-Male \& Onyango, 1984). This definition by Koyango and Onyango is prompted in the speech of Lavina about the solidarity that the concept of family stands for and which must be conserved. Titus' daughter said: "Lo, at this tomb my tributary tears I render, for my brethen's obsequies; and at thy feet I kneel, with tears of joy, shed on the earth, for thy return to Rome..." (Shakespeare, 2011: 446). However and based on British culture and tradition, each member of a community should feel being concerned by any problem that one of his or hers group is facing. In that logic, the family plays key roles in the salvation of people notably in the education of teenagers and young people as well. The empress, Tamora, in Titus Andronicus did it for her children in the fifteenth century against Titus' children by hiding the guilt of her children, the rapists of Lavinia, Titus' daughter. Thus, this implies that the group-face saving is an old practice. But 
the question here is on how is it conceived today or is it still adopted for the new generations?

As the basis for the teaching of children, it is obvious most of time, that the family convenes its meeting when there is a transgression in the family. So, most of the family's meetings occur either to solve and to forbid wrongdoings or to regain wayward youth or someone belonging to the group. Talking about the Bantu practices in his writing, Nimisi advocates that the forbidding acts should be those "actes susceptibles de favoriser l'éclosion de la vie, de conserver cette dernière, de la protéger, de l'épanouir ou d'augmenter le potentiel vital de la communauté et des individus considérés comme bons" (Nimisi , 1978 : 120). In other words, the 'Forbiddings' must help to fulfill, to save our descendants, protect and raise the vital potentiality of the community and its citizens who behave well. Based on that fact, any young man who makes efforts to succeed in his or her life is to be encouraged. Instead of helping and assisting the offspring, parents become passive, inoffensive, and spectators in their duties towards their children.

For instance, in the play, Titus instead of accepting the marriage between his daughter, Lavinia and her beloved Bassianius, Saturninus brother, one of the son of the late Roman Emperor, preferred to be obedient to the new Emperor Saturninus; focusing on the customs prescriptions which force to satisfy all the wants and desires of the emperor on the throne. For sure, a marriage is not only between the bride and the groom but with the two families and even with relatives. Yet, the marriage is between the two families but for the sustainability of their relation, the wedded opinion and desires must also be taken into account to avoid some unforeseen conflicts such as divorce, dispute, and quarrels. Parents' role is to allow the youngster defends himself or herself. In this way, it is not their concern to cater for the success of their relative. Therefore, they became somehow, responsible for the death of the startup genius among the youth through such an act. In this vein, Achebe reports Mr. Ukpabi Asika on the definition of unity and said it is "Absolute good" (Achebe, 2012: 13-14).

Family meetings must be taken as a pattern of unification of its members. It must be an avenue to give help to its members who want to prosper as it was observed from the side of Martius, the son of Titus, who is opposed to the relationship between Emperor Saturninus and Lavinia her sister. This is because; according to him it does not draw his sister to prosperity. Beyond the fact that family is a circle of support, help, and interrelation as portrayed through the acts of characters in Titus Andronicus, each family member has to be humble, and frank by involving themselves in a manner to do away with personal honor, prestige, and pride that are not contributing to the growth of the whole community. In that optic, Nathanaël Soédé, in one of his writings opines: 
L'humilité, l'effacement de soi devant l'autre et devant les événements...Un véritable dépouillement de soi, un renoncement aux honneurs, pouvoirs et biens de ce monde en ayant pour seule fin de devenir le grain qui meurt en terre pour que la vérité, la vie jaillisse des sacrifices et se développe au bénéfice de la communauté ${ }^{7}$ (N. Soédé, $2015: 57$ ).

And beyond this kind of family conception, parents should serve as a defensive tool or rampart of success for their children while they start something good for the whole group or for their personal development. Achebe (2012:14) adds "Unity can only be as good as the purpose for which it is desired. Obviously it is good for a group of people to unite to build a school or a hospital or a nation. But, supposing a group of other people get together in order to rob a bank". So, unity through meeting should be for the well-being of every member and not only to lay blame. Family's meeting can also be a means to help, and to encourage (Agyakwa, 1992; Bruno, 2011). That is the reason why question "How is it that it is only when there is misbehaviour or death that a meeting occurs in families?" becomes an imperative.

It is observed that the family name is that family's dignity that should be protected no matter what happens. Its members are involved in the defense of anything likely to spoil it. Thus, family in whole is taken as a common precious material for all its members. But unlikely nowadays, the group-face defense has been replaced by one-face defense through the French popular saying "Chacun pour soi Dieu pour tous." Individualism becomes obvious in such a way that it causes socio-economic and political conflicts. People from the same family and nation do not agree to be with or live together. They do not want to help one another. This attitude is undermining the ancient practice whereby a member of a family must be supported. For instance, the brave soldier, Titus, was defended by his relative, Lucius, while being maltreated by Saturninus the Roman Emperor. This was despite the glory he granted the whole nation. He refused Titus, his grand-father, from cutting his hand. Thus, he wanted to cut his own hand and send it to the Emperor as a proof of honesty and truth that incarnate the Titus' family. That act of Lucius is to tell the Emperor that Titus' sons, his uncles: Quintius and Mutius, are to be considered as full members of the nation. So, he does not want his children to be labeled as the rapists and the murderers of Lavinia and Bassianius respectively.

\footnotetext{
${ }^{7}$ See my translation about Nathanaël Soédé's explanation of family honesty “Humility, one's efficiency with his or her neighbor and in front of events...One's frank openness, resignation to honors, powers and wealth of this world in order to become the seed sown on the ground for the truth acceptance, as life based on sacrifices which spread for the well-being of the community".

${ }^{8}$ My translation the of French adage, "Every Man for himself, God for us all”.
} 
Thus, community needs, for example, acceptance and support on the part of kinsmen. This ranges, from brothers, sisters or even a friend or relative having shared his or her childhood. Many cases exemplify that aspect of communality and family concept worldwide. Among these, one of the former president of Benin Republic, Boni Yayi, and Patrice Talon, the current president of Benin reinforces this issue to open eyes on people in general and readers in particular. The two men as close friends of the same country which is Benin end up in furious enmity because of interests. ${ }^{9}$ Regarding the group, community, and nation name's saving, it is a duty for anyone to take care of his or her social group, and works for its flourishment. Those two men mentioned above could be avoided that conflict. They had to transgress their pride and selfishness, and join their political and economic potentials for the development of their community.

\section{Contemporary Conception of Family and Mentality-Keeping.}

The family name is an identity common to people under the same ancestor or tie. It allows recognizing the offspring of a grandfather. Family is therefore described as a kinship between members. It connects them one to another. So, people from the same ancestor, share the same tradition and customs. And so, they have to conserve that link which exists between them for generations. Viewed in that way, the problem of one of its members, is the concern of the whole tie. Thus, solidary becomes a priority for all its members. That assistance connected to solidary, forces to extend a family's tie to the relatives or people from the same social group. In this concern, the group's safety depends on each of its counterpart. So, the defense of the name of one's community, social group as well as family's name, becomes compulsory to him or her due to the kinship, which, is the blood attaching him or her to his or her counterparts.

Based on that, they should help and defend one another against the enemy. Aaron in Shakespeare's play Titus Andronicus acts in the same way while he was defending his child he has gotten from his mistress, Tamora, the Empress (Shakespeare, 2011: 458). He said:

[...] Coal-black is better than another hue,

In that it scorns to bear another hue;

For all the water in the ocean

Can never turn the swan's black legs in white,

Although she have them hourly in the flood.

Tell the empress from me, I am of age

\footnotetext{
${ }^{9}$ Patrice Talon was forced to go on exile namely in France for around three years. His businesses and business centers were blocked and locked. He was subjected to many suspicions towards Boni Yayi like coup d'état, food poisoning and his so-called accessaries were arrested and put in prison.
} 
To keep mine own, excuse it how she can [...] My mistress is my mistress; this myself, The vigour and the picture of my youth:

This before all the world do I prefer;

This maugre all the world will I keep safe, Or some of you shall smoke of it in Rome.

(Titus Andronicus IV, ii, 460)

The defense of the group-face through the protection of his son gotten from the adultery committed with the empress, Tamora, demonstrates how a family member is important in the family ties. For Aaron, even if the baby comes from a Black union with a White, it has the living right like any human being sharing same blood. But, such a behavior is disappearing since the introduction of the capitalist economic system in people's lives on the one hand whereby each one has to think only for himself or for one of his or her direct parents only. On the other hand, this way of acting today within a family is due to socio-economic disparity and inequality which draw way to the severance poverty: famine. Furthermore, this results to social ambivalence (richness and poverty) between people from the same group. It forces people to adopt lonely comportments to avoid being frustrated, since, the rich man is somehow, proud of his wealthy.

Parents' role is key in the process of educating a child. It is therefore up to parents to induce the know-how in their children. They have to teach the child how to behave in the society with his or her neighbors without hurdles and classes' considerations. In this regard, Achebe (2012:14) shares the opinion that: "“virtues' like unity and faith are not absolute but conditional on their satisfaction of other purposes. Their social validity depends on the willingness or the ability of citizens .... This calls for a habit of mental rigour". Symbolizing family's meeting as a pattern of unity; it must be an educational and a moral assembly for success for its relatives but not a session to draw on banishment. Indeed, these family's meetings could be an opportunity to sensitize youngsters on how they can implement their vision into actions. These should be occasions to insist young people to work hard, to share, and learn from their own experiences or from the ones of others.

Furthermore, mistrust or suspicion which exists among some people in the society forces parents to hide or not to share the wealth opportunity of their children with the whole family, thinking it will handicap the child's success. Aaron hid the birth of his son to the community. Even though it is normal at his age to have a child, that maybe could not be well welcomed by his countrymen owing to the racist ideology that was prevailing at that time. In view of that, people protect their children so as to help them grow. They don't want their descendents to go through the same painful situation, as they have weakly been assisted or subjected to it. In that connection, Nathanaël says: 
Qu'aucune blessure ne doit être banalisée. Tout ce qui représente une croix, un mal, un mépris de la dignité humaine assumé ou subi, est une souffrance à prendre en considération. Il est à mettre au service de la construction et de la reconstruction de toute personne, de toute communauté humaine, culturelle, politique, etc. Il faut en offrir la grâce aux hommes et femmes qui ont vécu des drames de la vie ainsi qu'à leurs bourreaux - lorsqu'ils existent - et aux autres membres de la société ${ }^{10}$. (Soédé, 2015: 46)

According to Soédé, the truth should be said anytime to spare people and family members of fear towards their neighbors. Before that, the community or family's meeting must be the device that teaches acceptance, tolerance and forgiveness in order to avoid jealousy and ignorance. It must not become the opportunity to hinder the success of the youth. Indeed, it is obvious to witness some sad situations. These force to talk of ignorance and jealousy that are prompted by injustice and honesty among people of the same family and nation. In that optic of the purposes of family's meeting, Achebe rhetorically asks:

Why did we not think, for example, of such concepts of Justice and Honesty which cannot be so easily directed to undesirable ends? Justice never prompts the question: justice for what? Neither does Honesty or Truth. Is it possible that as a nation we instinctively chose to extol easy virtues which are amenable to the manipulation of hypocrites, rather than difficult ones which would have imposed the strain of seriousness upon us? (Achebe, Op. Cit.: 14)

For him, it is not conceivable to say that we are together for the same aim, but we are not able to tell the truth to one another because of mistrust. That is the reason why Titus wonders about the fact that Saturninus, the new Roman emperor, privileged the captive, Tamora, and follows her advice which aims to destroy Titus' family. Such a behaviour can create a problem to the family or be an obstacle as it is the case of Titus' sons, Quintus and Martius, who were accused for being the murderers of Bassianus. This mistrust manifested towards the warrior of the Roman Empire and his family members, gives way to division and does not facilitate fair collaboration between the people of Rome.

\footnotetext{
${ }^{10}$ See my translation of Nathanaël's quotation. "Any injury or wound has not to be neglected. Whatever symbolizes pain, hatreds, mistrust that human dignity went through, is like body injuries that need to be considered. It will help to build and rebuild a personality, a community, culture, politics, etc. It must be offered to men and women who went through tragic events of life and their offenders as well - when they exist - and to other countrymen".
} 
Due to ignorance, mistrust and jealousy, people prefer protecting their relatives against a potential danger. Chiron and Demetrius were protected by the Empress Tamora for their murder and rape committed against Bassianus and Lavinia. In that perspective, goodness can be hidden to avoid creating suspicion or jealousy. The hiding of the baby by Aaron and Tamora is not the matter of colour as some could imagine. Aaron is Black and Tamora White, but whoever could imagine that Aaron could get a child from Tamora. This innocent and god's gift should be protected against potential attackers. Thus, people as well youngsters at a certain level of success prefer to hide their experiences to avoid adversity, jealousy that can jeopardize their evolution. Such a fact is posing a serious problem of mentality change and how people in general and relatives in particular conceive family as a concept.

\section{Changing of Mentality in Family Roles: Socio-Political and Economic Impacts of Youth Education.}

In general, the family is a circle in which children are educated either by their direct parents or relatives and even neighbours. This is based on the fact that there is a genealogical tie that links the people of a community, clan, nation, and family together. It goes without saying that, the success of the former leaders in general takes its root in it. The British political history of sixteen century exemplifies and sheds light on this fact. The two main political parties Whigs and Tories joined their efforts together thanks to Sir Robert Walpole, a British Whigs' parliamentarian, who defended parliamentarians' rights and forced King James II to exile in France. Finally they brought the Dutch Protestant William to UK's throne. All these happened due to the fact that James II did not want to rule the kingdom by collaborating with British parliament members. In 1903, Emmeline Pankhurst, the first leader of Women's Social and Political Union (WSPU), fought for the voting right of women in UK. She and her relatives fought against political injustice. They defended women's suffrage through petition addressed to the House of Commons by claiming the spreading of voting right to everyone; mainly to women.

In addition, the spreading of social injustice seems to be rooted in lack of mentality openness and greediness. In the name of tradition, there are people, who used to seek for the evil in every situation. They do not want to praise the good in the action. Why some can be deprived the rights to vote and others not. They are all, the citizens of the same nation. For a fair living standard, is there any need to deprive someone from his or her right? The answer of this question should be normally no. But, since each one is considering himself or herself as being more important and greater than others, the problem of social classes occurs and persists. And this, leads people, to misbehave towards their countrymen. They used to cheat on so as not to 
improve their populations living standards. This retrograde mentality based on creating problems for people by arresting them and even putting them into gail or prison, is to be stopped.

The retaliated mentality should be thrown away and give way to reciprocal trust in. Because, an immediate consequence of its conservation or keeping, draws way to the migration of skilled people, mainly the one of valid young people. They migrate into the areas, where, they seem to be in safety, and far from wicked people and havoc or hurdles. Such a thing forces to question leaders who do not arrive to end or reduce the speed of the phenomenon of individualism and mistrust. The old Titus behavior denotes that people should have mind openness. He was pre-detected as the successor of the late emperor of Roman Empire. But he gave the chance to the young Saturninus, the son of the late Roman Emperor, to rule the whole nation even though the latter, adopted towards him and his family ungrateful attitudes.

Youth should give opportunity to experience in order to shape their aptitude. Despite their high level and degrees in health, education, and security fields and so forth, they are not granted as much as possible the rate of being part of the decision making circles. And it seems that families as well leaders are not aware of what is going on with their counterparts in general and specifically the youth. They experience can be somehow benefit for the whole community. Tamora, the captive, the Goths' empress were taken as the first advisor by the Roman emperor Saturninus. Someone can be right while thinking that she was the main-former one (advisor) of the Goths late emperor. This is despite the fact that does not seem to be the case due to the fact, the Goths did not win the battle against the Romans. As such, her experience could be useful for the Roman entire nation. In that concern and to exemplify that thought, the current president of Benin Republic, Patrice Talon declared in an interview back from a trip: "Le Bénin, notre pays est un désert de competence $^{11}$ (Ortb Tv Interview, 2016)".

In other words and in contrary to what people can think, most skilled people of the country are forced to share their know-how abroad than in their own country. They prefer to serve in the international institutions seeking for better living conditions. They are praised outside of their country thanks to their managerial skills. Shakespeare's Titus Andronicus, denotes it through the solicitude behaviors manifested by the Emperor Saturninus towards the Goths Empress, Tamora. Tamora's attitude is an offensive one in this case. She came into Rome to show her skillful country's leading to Saturninus. She preferred being more efficient abroad than in her own country.

11 See my translation of Patrice Talon, Benin President while he was back from an international conference in France. He was talking about the mismanagement behavior spread in the country by its skilled managers. "Benin, our nation is a desert of competence" 
As human beings, some behave like Tamora did. They act to do this, either because of mistrust towards them or fear to be killed or because of layoffs prompted by jealousy. Saturninus knew that he had not the merit for being at the throne. The one who fought and won against adversaries abroad is Titus and his troop. Moreover, he was one of the kinsmen of the late Romans' Emperor. For that and since he can come for revenge, it will be better for Saturninus to soak him and its relatives for the sake of his throne. This complaisant attitude of leaders could not be an example or a pretest to justify young people passive attitude nowadays. Despite the hurdles and the saying according to which success and wealth are God's gift, they should go forward. They should afford situations. Each people have to work hard to reach their destiny no matter how and no matter what but in fair way.

\subsection{Contextualization and Understanding of Family's Meeting}

At times, it is obvious that any birth is preceded and followed by the Weird (Shakespeare, 2011: 471-5) or Fâ ${ }^{12}$ consultation to check about the sex unborn, his or her destiny, and to seek for the upcoming events in his or her life. This practice, allows preparing the welcoming of the baby. It helps also to do sacrifice like libation to implore and ask for the blessing of ancestors on the baby's life in order to strengthen him or her before unfair living situations such as death, mistrust, betrayal, lust. This is done taking into account and referring to the findings from the weirds' consultation. The prophecy takes many forms and it is based on the way it is performed in the given community. Banquo and Macbeth went to consult witches for their future Ashitey retakes Shakespeare's Macbeth and she reports the character Banquo in the following: ...sir, why do you look frightened at such good news? And you weird things? Are you imaginary or as real as you seem to be? You greet my friend with his present title, with prophecy of future nobility and promise of royalty. Tell me also what the future has in store for me... You will bring forth kings although you are none.... (Ashitey, 2011: 16)

Indeed, the prophecy allows knowing about someone's future. Banquo knows now than he cannot be a king. But he will help the king to lead the kingdom efficiently. Opposed to him, his friend Macbeth is predicted for the throne in future as revealed by the weirds. That will happen finally in the play's performance.

Originally, the weirds consultation happens very often in presence of a witness as observed in Shakespeare's Macbeth (Banquo and Macbeth). It is done in a family and in presence of family members, since it is a tradition

\footnotetext{
${ }^{12}$ See Weird in UK's tradition and culture in Shakespeare's Macbeth and Fâ in West African context.
} 
pattern. It gathers most the community members. Any relative has to attend the ceremony. And as such, it is deserved respect likewise it is for rituals in tradition. So, anyone who comes to step on it, should be severely punished and must be labeled as a wrong-doer. Then, the wrongdoer must be purified during ritual organized by his or her family in that prospect. If not he or she is no longer apart of the family. His or her attendance to any family meeting is not welcomed unless the ceremony of purification is made.

The ritual of purification gathers family members. They are also invited when a family member misbehaves or steps on social law. Focusing on that, families used to check on the wrongdoings in the part of the youth to justify their non-assistance for their economic and financial growth in the society. Such a thing is forcing the young man to blame and accuse himself or herself for being at the origin of his or her misery or social position among his or her relatives. This type of education is implemented with youngsters in such a way that a young man who succeeds socially and economically is still spreading it through generations. This phenomenon is reducing the number of talents for the community development. Therefore, young people instead of being trained to succeed and help or share his or her experiences with his or her relatives for the same goal; he or she is trained to be lazy and to beg. Moreover, if someone comes to gather the youths, it is to offer them drinks and talk things that are senseless instead of educating and sensitizing them about entrepreneurship for their own good and for the development of the family as well as the society.

The unfair practice hidden in family's tradition and culture leads to creating problems to others. Some people conserve, protect and promote it, because of their egoism and pride. Based on what is undergoing today as far as religions are concerned, this theory is on the way to be abandoned. Regarding the evolution of science and knowledge according to which any situation is not stable and thing can change; children's mind should be reshaped. Thus, the destiny can be modified if people work hard irrespective of their socio-professional status.

\subsection{The Change of Mentality and the Rethinking of Child Education.}

Many scholars and leaders opined that changes in mentality are the dynamic engines in every social unit and constitute, therefore, the foundation of cultural, social, political, and economic development. A Changing of mentality is present and takes a key place in the Western and African politicians and leaders speeches during conferences and workshops. Developing countries' programs for development are calling for the revisitation of people's mentality. The concept is present in almost every month but without a clear insight in how to rethink the education of children. It seems that the economic system named capitalism in take place in people's behaviors 
even in family. The practice of individualism and the promotion of oneself are prompted in family. Thus, the change of one's mentality, instead of being empty word, should start from the content and the understanding of the concept of the success of family members. Then, the concept of mentality change should overpass the simple call for individual consciousness.

People should know they are nothing without others. They should unite their forces in order to move obstacles to bring positive changes in their environments. Titus and his kinsmen behaviours exemplify it several times. In fact, Titus was sure that his sons are not the culprits of the death of Bassianus. He accepted to cut one of his hands to prove his faith and belief in his sons to Saturninus. Furthermore, he planned with his relative young, Lucius, to prove the innocence of his sons, Quintus and Martius. And they reached their goal, thanks to the young Lucius' keen interpretation of the writings did by of Lavinia, Titus' daughter to him. The three persons, Titus, young Lucius, and Lavinia, arrived to escape from Saturninus and Tamora's plan which was to destroy Titus' family. This is because most of the time, the sole undertaking does not draw to collective welfare. Thus, this is based on the fact that everyone is chasing and satisfying his or her own passion by throwing away the one of the group. So one's selfishness becomes the glaring path of one's domination on his or her neighbor for the satisfaction of his or her own needs.

Mentality change, therefore, should begin by the way of leading family's meeting, country's institutions, and their reinforcement to bring down poverty via educational guidance. In this vein, people who like the concept of Mental Change (Achebe, 2012) must have an openness of mind. By implementing that, it is together the family, nation development target could be reached, child will be aware that he or she has apart to play in his or her community. An adage says that go alone is faster with risks but go together is more efficient. In other words, the solidarity-keeping to overcome and reach sustainable development is to be promoted. Thus, families must educate youth in the way of collective improvement in order to reduce poverty. In connection to this, Pewissi stated:

Personal satisfaction beyond contributing anything to the social whole is the sense of pragmatism western feminists wag; their pragmatism destroys the community and empowers individuals as isolated entities. Yet, human beings are social beings, i.e., without society they are nothing. (A. Pewissi, 2017: 159-160)

By talking to gender empowerment, Ataféi is calling female in particular and people in whole to cultivate solidarity in their actions. A lonely performance does not lead and stand for going far. And it is not useful to make great effort to attend an insignificant objective. By solidarity, female in United Kingdom were granted their right to vote through WSPU movement. Therefore, parents, instead of emphasizing children's mistakes are rather 
expected to support them and teach solidarity-keeping in every action. They should give up the theory of non-assistance towards youth who are misbehaving; something which is making fragile the social bond that should exist in populations and their communities.

Indeed, only a frank solidarity within people, families, populations, and nations-whereby there are or not democratic principles to banish injustice and to end misery in this era of globalization challenged by terrorism-will achieve our common goal which is poverty collapsing. This frank and sincere solidarity, as a solution for success comes as motive to destroy laziness and selfishness; to reduce poverty which gives way to insecurity; to promote confidentiality and love in each one towards his or her relatives. Based on that patriotism experience, Achebe defines patriotism as:

an emotion of love directed by a critical intelligence. A true patriot will always demand the highest standards of his country and accept nothing but the best for and from his people. He will be outspoken in the condemnation of their short-comings without giving way to superiority, despair or cynicism...patriotism is not going to be easy or comfortable in a country as badly run (Achebe, 2012: 12).

Family must sow and cultivate friendship, and relationship among its members. That will be the bond which galvanizes and allows the family members to love and sustain one another in difficulties, unfair situations or circumstances. It will also teach them that they are one, single as a body with its members or parts, and when one of these is hurt, it is the whole body which suffers the pains and none cannot move or act without the help of the others. In this logic of sustainable unity, people in general and their related families in particular must dare to make their proper future by being seriously and effectively sincere in their collaboration i.e. attitudes towards one another. Here, the future is to be considered as our development, the nation, a continent growth as well as his countrymen, tradition, and culture which should help for the well-being of everybody. It is only by behaving this way; the well-being could be efficiently spread to all as beneficiaries of development earnings in this era of single market that the world is presently undergoing.

\section{Conclusion}

The family is the key component of any society which must be kept up since children's education depends on its role in the communities worldwide. Thanks to reader-response approach we made use of through this research work, it becomes obvious that the family should change its way of educating youngsters on their way to growth. Titus' attitude taught honesty and hardwork to his sons and his relatives. Tamora's act of defending the honor of his 
countrymen and the soul of her son, denotes her connection with her relatives. Family should aim at encouraging and assisting youngsters morally as well as financially. The strengthened mind plotting of Titus by Shakespeare shows that youth must be encouraged and be strong in their actions. It appears, therefore, that parents and relatives should accept one another by overcoming the social differences instead of being handicaps for their youth who are trying to be a Man.

In addition, it is important to mention that even though some could doubt about it, the Western and African tradition and culture do not have anything in the solitary attitude observed in some families. In contrary, the fact of acting and being together for dealing with business or solving problems allows youngsters to be competitive. This attitude of togetherness targets to reinforce the thought of unity that should be the strength of success of the community, nation, and family. Therefore, the Unity should be the masterpiece that each member of the community must look for and take as a challenge for the development of the whole nation in this era of globalization i.e., a single community.

\section{References:}

1. Achebe, C. (2012). The Trouble with Nigeria. England: Heinemann Educational Books.

2. Ashitey, A. (2011). William Shakespeare's Macbeth in Modern Prose, $2^{\text {nd }}$ ed. Accra: Innolink Limited, Kokomlemle.

3. Dravo (De), C. M. (2012). "Femme, mère de la renaissance africaine." In Revue Théologie Africaine, Eglise et Sociétés, 2. Abidjan: CFMA.

4. Dumas, J. (2000). L'enfant violent. Paris: Bayard.

5. Nimisi, C. M. E. (1978). L'homme dans l'univers des Bantu. 2ème édition, Lumumbashi: Presse de l'Université Nationale du Zaïre.

6. Soédé, Y. N. (2015). Un prisonnier appelé Alphonse Quenum: Interview d'un prophète de la vérité. Abidjan: ATA.

7. (2011). The Complete Works of Shakespeare. Mumbai: A Wilco Book.

8. Gyekye, K. (1996). African Cultural Values: An Introduction. Accra: Sankofa Publishing Company.

9. Hess, M. F. \& Downs, W. (2013). "Combating 'The Culture of Can't." In Frederick M. Hess Cage-Busting Leadership, USA: Havard Education Press. Pp.70-87.

10. Koyango-Male D. and Onyango P. (1984). The Sociology of the African Family, Burnt Hill, Longman Group, accessed on html www. Sciences humaines.com/education, 12/10/2016. 
11. Magesa, L. (1997). African Religion: The Moral Traditions of Abundant Life, Nairobi: Paulines Publications Africa.

12. Nkamanbeng, M. (2014). Waiting for the Waves, Johannesburg: LANSM Publishing Ltd, html ganteng.net, accessed on 06/10/2016.

13. Price-Mitchell, M. (2015). Tomorrow's Change Makers: Reclaiming the Power of Citizenship for a New Generation, Bainbridge Island: Eagle Harbor Publishing, accessed on html www.amazon.com, 06/10/2016.

14. Pewissi, A. (2017). Rethinking Womanism: When Differnce Maps Chaos, Accra-Ghana: Yamens Press Ltd.

15. Wehmeier, S. (2006). Oxford Advanced Learner's Dictionary of Current English. New 7th Ed, Oxford: Oxford University Press. 